\title{
Accuracy of an intraoral digital impression: A review
}

\author{
Kanchan Aswani $^{1^{*}}$, Sattyam Wankhede ${ }^{2}$, Arun Khalikar ${ }^{3}$, Suryakant Deogade ${ }^{4}$ \\ ${ }^{\mathbf{1}}$ Post Graduate Student, ${ }^{2,4}$ Associate Professor, ${ }^{3}$ Professor and HOD, ${ }^{1-4}$ Dept. of Prosthodontics and Crown \& Bridge, ${ }^{\mathbf{1 - 4}}$ Govt. Dental \\ College and Hospital, Nagpur, Maharashtra, India
}

\begin{abstract}
Introduction: Intraoral scanners are used for capturing the direct optical impressions in dentistry. The development of 3D technology and the rising trend of increased use of intra-oral scanners in dental office routine lead to the need to assess the accuracy of intraoral digital impressions

Aim: The aim of this review was to assess the accuracy of the different intraoral scanners and the effect of different variables on the accuracy outcome.

Materials and Methods: An electronic search using Pubmed with specific keywords were used to obtain potential references for the review.

Results: Total 21 articles were selected according to the inclusion criteria of which 18 were in vitro studies and 3 were in vivo, 15 articles had studied full arch scanning.

Conclusion: The studies indicated variable outcome of the different intraoral scanner systems. While the accuracy of intraoral scanner systems appears to be promising and comparable to conventional methods, they are still vulnerable to inaccuracies.
\end{abstract}

Keywords: Digital impression, Optical impression, Intraoral scanner, Accuracy.

\section{Introduction}

With the advancement in digital dentistry, computer-aided design and computer-aided manufacturing (CAD-CAM) technology has increased in popularity and provides more efficient and predictable treatment outcomes.

The acquisition of 3-dimensional (3D) images has improved conventional prosthetic approaches and has made it possible to virtually define treatment planning, to design and mill restorations. Different technologies and principles are used to create this virtual image, and their application differs according to the scanned tissue. With the demand for simplification of cumbersome conventional impression procedures, the use of intraoral scanners (IOSs) has increased. The intraoral digital scanning technique is more rapid and convenient, from the perspective of both, the dentist and the patient. ${ }^{1}$

Numerous advantages are offered by digital intraoral scanning, such as: real-time visualization, easy repeatability, selective capture of the relevant areas, no need to disinfect and clean dental impressions and impression trays, no wear of the model, rapid communication and availability. ${ }^{2}$ Different intraoral scanners by the numbers of company are increasing that offer user friendly, perceived as pleasant for the patient ${ }^{3,4}$ and time efficient. ${ }^{5,6}$

Dental impressions, either conventional or digital, are intended to obtain a copy (imprint) of one or several prepared teeth, adjacent and antagonist with the interocclusal relationship. ${ }^{7}$ Therefore the accuracy of the impression is the key aspect that reflects the definitive outcome of the restoration. Beyond the operational and clinical differences (speed of use, need of powder, size of the tips) and cost (purchase and management) between different machines, the most important element to be considered should be the quality of the data derived from scanning, which is defined as "Accuracy". ${ }^{8}$ Accuracy is the combination of two elements, both important and complementary: "trueness" and "precision"s. The term "trueness" refers to the ability of a measurement to match the actual value of the quantity being measured ${ }^{8}$. Precision is defined as the ability of a measurement to be consistently repeated: in other words, the ability of the scanner to ensure repeatable outcomes, when employed in different measurements of the same object. ${ }^{8}$

Different scanning techniques are being implemented in different intraoral scanners, that may yield different scanning accuracies. Therefore, the purpose of this review was to compare the accuracy of different intraoral scanners and the effect of different variables on the accuracy outcome.

\section{Study design and methods}

An electronic search of published scientific papers was performed using the PubMed database of Medline incorporating specific keywords: digital impression, optical impression, intraoral scanner and accuracy in various combinations to obtain potential references for review. Articles were collected according to the inclusion criteria, which include studies, in-vitro or in-vivo orin-vivo, quantitative results provided, articles in English language, excluding the articles other than in English, literature review, article that evaluate the marginal adaptation of the fabricated restoration, scanning done for digital implant

\footnotetext{
*Corresponding Author: Kanchan Aswani, Dept. of Prosthodontics and Crown \& Bridge, Govt. Dental College and Hospital, Nagpur, Maharashtra, India

Email: kanchanaswani2@gmail.com

http://doi.org/10.18231/j.aprd.2019.013
} 
impression or implant supported prosthesis and duplicates were discarded.

\section{Results}

A search of MEDLINE (PubMed) identified 507 articles. After title and abstract screening, 412 articles were excluded for not meeting the inclusion criteria or because the data could not be extracted and discarding duplicate references. 95 articles were followed for full screening; only 21 were included in the final analysis. (Table 1)

\section{Discussion}

The purpose of the present review was to determine the accuracy of the different intraoral scanners and the effect of different variables on the accuracy outcome. There are various factors that affect the reproducibility of an intraoral scanner, including the scanning technology, data processing algorithm, whether or not to use powder and image acquisition method. Active triangulation is a traditional scanning technology and has been frequently applied, which offers the highest trueness if the condition is right. ${ }^{21}$ In comparison, the parallel confocal technology does not require a certain distance for focusing, and thus images can be acquired regardless of whether the scanner tip is attached to the teeth when the oral cavity is scanned. ${ }^{21}$ On the other hand, the optical coherence tomography has a high resolution that can create an image of the micromorphology of the abutment by combining the optical interference phenomenon and the confocal microscopy technology. ${ }^{21}$ Park ${ }^{21}$ reported that the type of restoration, the preparation out line form, the scanning technology and the application of powder have an influence on the accuracy of the intraoral scanner.

Hack ${ }^{16}$ reported the Trios to be most accurate (trueness $6.9 \pm 0.9 \mu \mathrm{m}$ and precision $4.5 \pm 0.9 \mu \mathrm{m}$ ) when scanned for single tooth compared to the other scanners (True definition, ITero, CS3500, Omnicam and Planscan) and Omnicam and Planscan to be least accurate. Even a study conducted by Guth et al, ${ }^{24}$ showed that Cerec Bluecam and Omnicam were least accurate in terms of truness, compared to the other scanners (CS3500, Zfx Intrascan CEREC AC Bluecam, CEREC AC Omnicam, True Definition) with the True Definition and CS 3500 to be most accurate when used to scan a titanium model for four unit FPD.

The most critical component in prosthodontics for fixed prosthesis is the finish line accuracy when intraoral scanners are used. Nedelcu et $\mathrm{al}^{25}$ studied the finish line distinctness and finish line accuracy in 7 intraoral scanners $(3 \mathrm{M}$, CS3500 and CS3600, DWIO, Omnicam, Planscan and Trios.) TRIOS displayed the highest level of finish line distinctness and together with CS3600, the highest finish line accuracy, DWIO and PLAN on the other hand displayed a generally low level of finish line distinctness and finish line accuracy. ${ }^{25}$ Thus, the author ${ }^{25}$ concluded that there are sizeable variations between intraoral scanners with both higher and lower finish line distinctness and finish line accuracy. High finish line distinctness was more related to high localized finish line resolution and non-uniform tessellation, than to high overall resolution, Color output from some scanners may enhance the identification of the finish line due to contrasting colors, but is dependent on the underlying technology. ${ }^{25}$

In vitro scanning done for complete arch by $\mathrm{Kim}$ et $\mathrm{al}^{1}$ using 9 intraoral scanners found that median average trueness values was better for Trios as compared to the E4D and Zfx IntraScan scanners, which were found to be least accurate for full arch scan. The authors also observed that Fast Scan and True Definition IOSs, which require a powder coating before scanning, exhibited significantly better trueness than IOSs that did not require powdering. ${ }^{1}$

Another study on scanning complete arch model by Ender and Mehl ${ }^{9}$ compared the accuracy of digital scanning (Lava COS and CEREC Bluecam) to conventional impressions (Impregum) and reported similar trueness between the digital and conventional impressions, whereas the CEREC Bluecam showed significantly higher precision than the conventional and Lava COS. However, Patzeldt et $\mathrm{al},{ }^{10}$ in their evaluation of 4 IOSs (CEREC Bluecam, iTero, Lava COS, and Zfx Intra Scan), demonstrated that the CEREC Bluecam was the least accurate (trueness $332.9 \pm 64.8 \mu \mathrm{m}$; precision $99.1 \pm 37.4 \mu \mathrm{m}$ ) and highest accuracy was observed with the Lava C.O.S. (trueness $38.0 \pm 14.3 \mu \mathrm{m}$; precision $37.9 \pm 19.1 \mu \mathrm{m})$. Similar findings were observed by the same author in 2014 while determining the accuracy of computer-aided design/ computer-aided manufacturing-generated dental casts based on intraoral scanner data. ${ }^{12}$

A study by Jeong et al, ${ }^{17}$ based on complete arch model digital impressions proves that, the impressions obtained by the Omnicam intraoral video scanner were more accurate than those obtained by the Bluecam intraoral still image scanner.

Ender and Mehl ${ }^{13}$ analyzed the accuracy of 4 different intraoral scanners and 4 different impression materials. The results revealed that CEREC Bluecam was the most accurate (trueness $29.4 \pm 8.2 \mu \mathrm{m}$, and precision $19.5 \pm 3.9$ $\mu \mathrm{m}$ ) followed by iTero (trueness $32.4 \pm 7.1 \mu \mathrm{m}$, precision $36.4 \pm 21.6 \mu \mathrm{m}$ ), then Omnicam (trueness $37.3 \pm 14.3 \mu \mathrm{m}$, precision $35.5 \pm 11.4 \mu \mathrm{m}$ ), followed by Lava COS (trueness $44.9 \pm 22.4 \mu \mathrm{m}$, precision $63.0 \pm 21.6 \mu \mathrm{m}$ ). The authors concluded that digital systems with single image stitching (iTero and CEREC Bluecam) showed local deviations at the terminal end of the arch, whereas the video-based systems (CEREC Omnicam and Lava COS) showed compression of the dental $\operatorname{arch}^{13}$ and also stated that deviations of $100 \mu \mathrm{m}$ and above across the full arch may lead to inaccurate fitting of the maxilla and mandible, which can be problematic in the case of large rehabilitations. ${ }^{13}$ Even other studies have postulated that digital impressions show distortion of the distal aspect when used to scan a complete arch. ${ }^{29,26,14}$

Treesh et $\mathrm{al}^{26}$ in his study of complete arch accuracy with 4 different intraoral scanners (CEREC Bluecam, CEREC Omnicam, TRIOS Color, and Carestream CS3500) found that Trios was most accurate among the scanners and CS3500 was the least whereas Renne et $\mathrm{al}^{18}$ had found that CS3500 performs better than the CEREC 
Table 1: Studies including the accuracy of different intraoral scanner

\begin{tabular}{|c|c|c|c|c|}
\hline Study & $\begin{array}{l}\text { Study } \\
\text { design }\end{array}$ & $\begin{array}{c}\text { Objective } \\
\text { (parameter measured) }\end{array}$ & Model & Intraoral Scanner used \\
\hline $\begin{array}{l}\text { Andreas ender et } \\
\mathrm{al}(2011)^{9}\end{array}$ & In vitro & Accuracy & Complete arch model & $\begin{array}{l}\text { Cerec AC Bluecam } \\
\text { Lava COS }\end{array}$ \\
\hline $\begin{array}{l}\text { Sebastian B. M. } \\
\text { Patzelt et al } \\
(2013)^{10}\end{array}$ & In vitro & $\begin{array}{l}\text { Accuracy of intraoral } \\
\text { scanners in full-arch } \\
\text { scans }\end{array}$ & Model with 14 pre- pared abutments & $\begin{array}{l}\text { iTero, CEREC AC Bluecam, } \\
\text { Lava C.O.S., and Zfx IntraScan }\end{array}$ \\
\hline $\begin{array}{l}\text { Sebastian B.M. } \\
\text { Patzelt et al } \\
(2013)^{11}\end{array}$ & In vitro & $\begin{array}{l}\text { Feasibility } \\
\text { and accuracy of } \\
\text { digitizing edentulous } \\
\text { jaw models }\end{array}$ & Edentulous jaw models & $\begin{array}{l}\text { CEREC AC Bluecam, } \\
\text { Lava Chairside Oral Scanner } \\
\text { C.O.S., } \\
\text { iTero, Zfx IntraScan }\end{array}$ \\
\hline $\begin{array}{l}\text { Sebastian B.M. } \\
\text { Patzelt et al } \\
(2014)^{12}\end{array}$ & In vitro & Accuracy of full-arch & Full-arch polyurethane cast & $\begin{array}{l}\text { iTero Lava Chairside Oral } \\
\text { Scanner } \\
\text { CEREC AC Bluecam }\end{array}$ \\
\hline $\begin{array}{l}\text { Andreas Ender et } \\
\operatorname{al}(2015)^{13}\end{array}$ & In vitro & Accuracy & $\begin{array}{l}\text { Steel reference model fabricated from } \\
\text { maxillary impression with two full crown and } \\
\text { one inlay preparation }\end{array}$ & $\begin{array}{l}\text { CEREC Bluecam, CEREC } \\
\text { Omnicam, Cadent iTero, Lava } \\
\text { COS, }\end{array}$ \\
\hline $\begin{array}{l}\text { Andreas Ender et } \\
\text { al }(2015)^{14}\end{array}$ & In vivo & Precision & Five participants with a complete dentition & $\begin{array}{l}\text { CEREC Bluecam CEREC } \\
\text { Omnicam Cadent iTero, } \\
\text { Lava COS True Definition } \\
\text { Scanner 3Shape Trios 3Shape } \\
\text { Trios Color }\end{array}$ \\
\hline $\begin{array}{l}\text { Ting-shu Su et al } \\
(2015)^{15}\end{array}$ & In vitro & $\begin{array}{l}\text { Repeatability of } \\
\text { intraoral digital } \\
\text { impression scanning } \\
\text { with the repeatability of } \\
\text { extraoral scanning }\end{array}$ & $\begin{array}{l}\text { Nissin Dental Study Model (upper jaw) with } \\
\text { prepared abutments designed to form } 5 \text { set of } \\
\text { arrangements arrangement } 1 \text { : single prepared } \\
\text { maxillary central incisor; arrangement 2: } \\
\text { single prepared maxillary first molar; } \\
\text { arrangement 3: prepared central incisor and } \\
\text { canine with the lateral incisor absent; } \\
\text { arrangement 4: half of upper arch with } 7 \\
\text { prepared teeth; arrangement 5: entire upper } \\
\text { arch with } 14 \text { prepared teeth }\end{array}$ & TRIOS intraoral digital scanner \\
\hline $\begin{array}{l}\text { Gary D. Hack et } \\
\operatorname{al}(2015)^{16}\end{array}$ & In vitro & Accuracy & $\begin{array}{l}\text { Typodont teeth - first right maxillary molar } \\
\text { prepared for all- ceramic crown }\end{array}$ & $\begin{array}{l}\text { iTero True Definition PlanScan } \\
\text { CS } 3500 \text { TRIOS CEREC AC } \\
\text { Omnicam }\end{array}$ \\
\hline $\begin{array}{l}\text { Il-Do Jeong et } \\
\operatorname{al}(2015)^{17}\end{array}$ & In vitro & $\begin{array}{l}\text { Accuracy of complete- } \\
\text { arch model }\end{array}$ & Complete-arch model & $\begin{array}{l}\text { CEREC Omnicam, } \\
\text { CEREC Bluecam }\end{array}$ \\
\hline $\begin{array}{l}\text { Walter Renne et } \\
\text { al }(2016)^{18}\end{array}$ & In vitro & $\begin{array}{l}\text { Accuracy(trueness and } \\
\text { precision) }\end{array}$ & $\begin{array}{l}\text { Custom complete-arch model scanned for } \\
\text { posterior sextant and complete arch. }\end{array}$ & $\begin{array}{l}\text { CEREC omnicam, } \\
\text { CEREC Bluecam, Planmeca, } \\
\text { Planscan, Cadent iTero, } \\
\text { Carestream 3500, 3Shape } \\
\text { TRIOS } 3\end{array}$ \\
\hline $\begin{array}{l}\text { Balint Vecsei et } \\
\text { al }(2016)^{19}\end{array}$ & In vitro & accuracy & $\begin{array}{l}\text { Partially edentulous PMMA maxillary master } \\
\text { cast with four full crown preparations with a } \\
\text { shoulder finishing line }\end{array}$ & $\begin{array}{l}\text { iTero, Trios and CEREC } \\
\text { Omnicam }\end{array}$ \\
\hline $\begin{array}{l}\text { Jong-Eun } \\
\operatorname{Kim}(2016)^{20}\end{array}$ & In vitro & Accuracy & $\begin{array}{l}\text { Mandibular model containing } 4 \text { prepared teeth } \\
\text { and an edentulous space of } 26 \mathrm{~mm} \text { in length }\end{array}$ & $\begin{array}{l}\text { CS3500 Cerec Omnicam } \\
\text { Trios }\end{array}$ \\
\hline $\begin{array}{l}\text { Ji-Man Park } \\
(2016)^{21}\end{array}$ & In vitro & $\begin{array}{l}\text { Reproducibility among } \\
\text { intraoral scanners }\end{array}$ & phantom model containing five prepared teeth & $\begin{array}{l}\text { E4D dentist, Fastscan, iTero, } \\
\text { Trios and Zfx Intrascan }\end{array}$ \\
\hline $\begin{array}{l}\text { F. Kuhr et al } \\
(2016)^{22}\end{array}$ & In vivo & $\begin{array}{l}\text { Accuracy of full arch } \\
\text { impressions in patients }\end{array}$ & $\begin{array}{l}\text { Four metal spheres fixed with composite using } \\
\text { a metal application aid to the lower teeth of } 50 \\
\text { test subjects as reference structures }\end{array}$ & $\begin{array}{l}\text { Sirona CEREC Omnicam , } 3 \mathrm{M} \\
\text { True Definition , Heraeus Cara } \\
\text { TRIOS }\end{array}$ \\
\hline $\begin{array}{l}\text { Ji-won Anh et al } \\
(2016)^{23}\end{array}$ & In vitro & Precision & $\begin{array}{l}\text { Maxillary models of } 4 \text { different arch length } \\
\text { with resin teeth }\end{array}$ & iTero and Trios \\
\hline $\begin{array}{l}\text { Jan-Frederik } \\
\text { Güth et al } \\
(2017)^{24}\end{array}$ & In vitro & Accuracy & $\begin{array}{l}\text { A titanium model with a premolar and molar } \\
\text { with a chamfer preparation representing the } \\
\text { base for a four-unit FDP }\end{array}$ & $\begin{array}{l}\text { CS 3500, } \\
\text { Zfx Intrascan, CEREC AC } \\
\text { Bluecam, CEREC AC } \\
\text { Omnicam, True Definition } \\
\end{array}$ \\
\hline $\begin{array}{l}\text { Robert Nedelcu } \\
\text { et al }(2018)^{25}\end{array}$ & In vitro & $\begin{array}{l}\text { Finish line distinctness, } \\
\text { and finish line accuracy }\end{array}$ & $\begin{array}{l}\text { Dental model with a crown preparation } \\
\text { including supra and subgingival finish line }\end{array}$ & $\begin{array}{l}\text { 3M True Definition, } \\
\text { Care- stream CS3500 CS3600, } \\
\text { Dentalwings Intraoral }\end{array}$ \\
\hline
\end{tabular}




\begin{tabular}{|l|l|l|l|l|}
\hline & & & & $\begin{array}{l}\text { Scanner,Omnicam, Planscan } \\
\text { and Trios }\end{array}$ \\
\hline $\begin{array}{l}\text { Joshua C. Treesh } \\
\text { et al (2018) }\end{array}$ & In vitro & $\begin{array}{l}\text { Accuracy for complete } \\
\text { arch }\end{array}$ & Maxillary complete-arch reference cast & $\begin{array}{l}\text { CEREC Bluecam, CEREC } \\
\text { Omnicam, 3Shape TRIOS } \\
\text { Carestream CS 3500 }\end{array}$ \\
\hline $\begin{array}{l}\text { Ryan Jin-Young } \\
\text { Kim et al (2018) }\end{array}$ & In vitro & $\begin{array}{l}\text { trueness and precision } \\
\text { of complete- arch }\end{array}$ & $\begin{array}{l}\text { Bimaxillary complete-arch model with various } \\
\text { cavity preparations }\end{array}$ & $\begin{array}{l}\text { CEREC Omnicam } \\
\text { CS 3500 E4D Dentist iTero } \\
\text { PlanScan Trios True Definition } \\
\text { Zfx IntraScan FastScan }\end{array}$ \\
\hline $\begin{array}{l}\text { Kyung-Min Lee } \\
(2018)^{27}\end{array}$ & In vivo & Accuracy & $\begin{array}{l}\text { 32 participates were scan for Maxillary as well } \\
\text { as mandibular arch }\end{array}$ & TRIOS and iTero \\
\hline $\begin{array}{l}\text { Junaid Malik et } \\
\text { al (2018) }\end{array}$ & In vitro & $\begin{array}{l}\text { Accuracy (ie, precision } \\
\text { and trueness) of full- } \\
\text { arch }\end{array}$ & $\begin{array}{l}\text { Model of a maxillary arch form } \\
\text { Trios, 3Shape, and CEREC } \\
\text { Omnicam, Sirona }\end{array}$ \\
\hline
\end{tabular}

Bluecam, CEREC Omnicam for full arch scan but when the same scanner were used to scan the sextants, CS3500 was less accurate than the two. Authors gave the conclusion that scanners differ with respect to, the speed, trueness, and precision of sextant scans, with the Planscan and the CEREC Omnicam providing the best combination of speed, trueness, and precision and 3Shape TRIOS for the complete arch scan. ${ }^{18}$

Kyung-Min Lee $^{27}$ found no statistically significant difference between the Trios and iTero scanners. Even Anh et $\mathrm{al}^{23}$ in their results showed the same when comparing the precision of the Trios and iTero. But the scanning strategies shown to affect the accuracy. ${ }^{23,30,31}$

In 2018 Malik et $\mathrm{al}^{28}$ observed that conventional fullarch polyvinyl siloxane impressions exhibited higher accuracy compared to two direct optical scanners (Trios, 3Shape, and CEREC Omnicam, Sirona). Similar results were found in various in-vivo and in-vitro studies ${ }^{14,22,29,13}$, where different scanners were used to scan complete arch impressions and compared against the conventional technique. So, an optical scanner seems to perform better in an in vitro environment, and their accuracy seems to be reduced in vivo as patient- specific factors, such as anatomic restrictions, movement, saliva, and soft tissue, affect the accuracy of scan. ${ }^{32,14}$

Software version used for scanning can have a significant impact on the accuracy of an intraoral scanner has also been reported. ${ }^{33}$ Nedelcu and Persson ${ }^{34}$ observed that even the type of material being scanned has a significant impact on the accuracy of the scanner.

$\mathrm{Su}$ and $\mathrm{Sun}^{15}$ reported decline in precision of intraoral digital impression with the increase in area of scanned arch. Precision was clinically acceptable when scanning scope was less than half arch, that means the larger and more complicated the scan area, the lower the accuracy. ${ }^{19,15}$ Therefore, it is difficult to compare individual studies directly, in order to arrive at a general conclusion regarding the accuracy of intraoral scanners. Studies done in an invitro set-up , for the digitization of an edentulous arch using intra-oral scanners, proved feasible yet research needs to be propagated to recommend using them in-vivo. ${ }^{20,11}$

Indeed, studies ${ }^{35-38}$ have demonstrated that fabrication of single unit and short span prostheses using an intraoral scanner lead to equal or even improved adaptation of prostheses compared to conventional impressions.

Digital dentistry is gaining increasing popularity and is showcasing good potential; however further studies are needed to assess and compare the clinical accuracy of digital impression technique for complete arch. An amalgamation of the digital and conventional approach may provide the added benefits in clinical practice, in specific relation to the treatment strategies planned for each case.

\section{Conclusion}

Digital intraoral impression systems continue to undergo rapid development. The accuracy of intraoral scanner is affected by several factors including the scanner technology, use of powder material being scanned, software for scanning, scanning strategy. Intraoral scanning systems in comparison to conventional impressions can be reliably used for diagnostic purposes and short-span scanning. However, for whole arch scanning, the intraoral scanner is susceptible to more deviation. The studies indicated variable outcomes for the different intraoral scanner systems. While the accuracy of intraoral scanner systems appears to be promising and comparable to conventional methods, they are still vulnerable to inaccuracies.

\section{Source of Funding}

None.

\section{Conflict of Interest}

None.

\section{References}

1. Kim RJY, Park JM, Shim JS. Accuracy of 9 intraoral scanners for complete-arch image acquisition: A qualitative and quantitative evaluation. J Prosthet Dent 2018;1-10.

2. Zimmermann.M, Mehl.A, Mörmann.W.H, Reich.S. Intraoral scanning systems - a current overview. Int J Comput Dent 2015;18(2):101-29.

3. Yuzbasioglu E, Kurt H, Turunc R, Bilir H. Comparison of digital and conventional impression techniques: Evaluation of patients' perception, treatment comfort, effectiveness and clinical outcomes. BMC Oral Health 2014;14(1):1-7.

4. Burhardt L, Livas C, Kerdijk W, van der Meer WJ, Ren Y. Treatment comfort, time perception, and preference for conventional and digital impression techniques: A comparative study in young patients. Am J Orthod Dentofac Orthop 
2016;150(2):261-7

5. Joda T, Brägger U. Digital vs. conventional implant prosthetic workflows: a cost/time analysis. Clin Oral Implants Res 2015;26(12):1430-5.

6. Patzelt SBM, Lamprinos C, Stampf S, Att W. The time efficiency of intraoral scanners. J Am Dent Assoc 2014;145(6):542-51.

7. Carbajal Mejía JB, Wakabayashi K, Nakamura T, Yatani H. Influence of abutment tooth geometry on the accuracy of conventional and digital methods of obtaining dental impressions. J Prosthet Dent 2017;118(3):392-9.

8. Imburgia M, Logozzo S, Hauschild U, Veronesi G, Mangano C, Mangano FG. Accuracy of four intraoral scanners in oral implantology: A comparative in vitro study. BMC Oral Health 2017;17(1):1-13.

9. Ender A, Mehl A. Full arch scans: conventional versus digital impressions--an in-vitro study. Int J Comput Dent 2011;14(1):11-21

10. Patzelt SBM, Emmanouilidi A, Stampf S, Strub JR, Att W. Accuracy of full-arch scans using intraoral scanners. Clin Oral Investig 2014;18(6):1687-94.

11. Patzelt SBM, Vonau S, Stampf S, Att W. Assessing the feasibility and accuracy of digitizing edentulous jaws. JADA 2013;144(8):914-20.

12. Patzelt SBM, Bishti S, Stampf S, Att W. Accuracy of computer-aided design/computer-aided manufacturinggenerated dental casts based on intraoral scanner data. J Am Dent Assoc 2014;145(11):1133-40.

13. Ender A, Mehl A. In-vitro evaluation of the accuracy of conventional and digital methods of obtaining full-arch dental impressions. Quintessence Int. 2015; 46(1):9-17.

14. Ender A, Attin T, Mehl A. In vivo precision of conventional and digital methods of obtaining complete-arch dental impressions. J Prosthet Dent 2016;115(3):313-20.

15. Su T shu, Sun J. Comparison of repeatability between intraoral digital scanner and extraoral digital scanner: An in-vitro study. J Prosthodont Res 2015;59(4):236-42.

16. Hack GD, Patzelt SBM. Evaluation of the Accuracy of Six Intraoral Scanning Devices: An in-vitro Investigation. $A D A$ Prof Prod Rev 2015;10(4):1-5.

17. Jeong ID, Lee JJ, Jeon JH, Kim JH, Kim HY, Kim WC. Accuracy of complete-arch model using an intraoral video scanner: An in vitro study. J Prosthet Dent 2016;115(6):755-9.

18. Renne W, Ludlow M, Fryml J, Schurch Z, Mennito A, Kessler $R$, et al. Evaluation of the accuracy of 7 digital scanners: An in vitro analysis based on 3-dimensional comparisons. J Prosthet Dent 2017;118(1):36-42.

19. Vecsei B, Joós-Kovács G, Borbély J, Hermann P. Comparison of the accuracy of direct and indirect three-dimensional digitizing processes for CAD/CAM systems - An in vitro study. J Prosthodont Res 2017;61(2):177-84.

20. Kim JE, Amelya A, Shin Y, Shim JS. Accuracy of intraoral digital impressions using an artificial landmark. J Prosthet Dent 2017;117(6):755-61.

21. Park JM. Comparative analysis on reproducibility among 5 intraoral scanners: sectional analysis according to restoration type and preparation outline form . J Adv Prosthodont 2016;8:354-62

22. Kuhr F, Schmidt A, Rehmann P, Wöstmann B. A new method for assessing the accuracy of full arch impressions in patients. J Dent 2016;55:68-74.
23. Anh JW, Park JM, Chun YS, Kim M, Kim M. A comparison of the precision of three-dimensional images acquired by 2 digital intraoral scanners: Effects of tooth irregularity and scanning direction. Korean J Orthod 2016;46(1):3-12.

24. Güth JF, Runkel C, Beuer F, Stimmelmayr M, Edelhoff D, Keul C. Accuracy of five intraoral scanners compared to indirect digitalization. Clin Oral Investig 2017;21(5):1445-55.

25. Nedelcu R, Olsson P, Nyström I, Thor A. Finish line distinctness and accuracy in 7 intraoral scanners versus conventional impression: An in vitro descriptive comparison. BMC Oral Health 2018;18(1):1-11.

26. Treesh JC, Liacouras PC, Taft RM, Brooks DI, Raiciulescu S, Ellert DO, et al. Complete-arch accuracy of intraoral scanners. J Prosthet Dent 2018;1-7.

27. Lee KM. Comparison of two intraoral scanners based on threedimensional surface analysis. Prog Orthod 2018;19(1).

28. Malik J, Rodriguez J, Weisbloom M, Petridis H. Comparison of Accuracy Between a Conventional and Two Digital Intraoral Impression Techniques. Int J Prosthod 2018;31(2):107-13.

29. Ender A, Mehl A. Accuracy of complete-Arch dental impressions: A new method of measuring trueness and precision. J Prosthet Dent 2013;109(2):121-8.

30. Medina-Sotomayor P, Pascual MA, Camps AI. Accuracy of four digital scanners according to scanning strategy in complete-arch impressions. PLoS ONE 13(9): e0202916.

31. Müller P, Ender A, Joda T, Katsoulis J. Impact of digital intraoral scan strategies on the impression accuracy using the TRIOS Pod scanner. Quintessence Int 2016;47(4):343-9.

32. Flügge T V., Schlager S, Nelson K, Nahles S, Metzger MC. Precision of intraoral digital dental impressions with iTero and extraoral digitization with the iTero and a model scanner. Am J Orthod Dentofac Orthop 2013;144(3):471-8.

33. Haddadi Y, Bahrami G, Isidor F. Effect of Software Version on the Accuracy of an Intraoral Scanning Device. Int $J$ Prosthod 2018;31:375-6.

34. Nedelcu RG, Persson ASK. Scanning accuracy and precision in 4 intraoral scanners: An in vitro comparison based on 3dimensional analysis. J Prosthet Dent 2014;112(6):1461-71.

35. Ender A, Zimmermann M, Attin T, Mehl A. In vivo precision of conventional and digital methods for obtaining quadrant dental impressions. Clin Oral Investig 2016;20(7):1495-504.

36. Ueda K, Beuer F, Stimmelmayr M, Erdelt K, Keul C, Güth JF et al. Fit of 4-unit FDPs from $\mathrm{CoCr}$ and zirconia after conventional and digital impressions. Clin Oral Investig 2016;20(2):283-9.

37. Su TS, Sun J. Comparison of marginal and internal fit of 3-unit ceramic fixed dental prostheses made with either a conventional or digital impression. J Prosthet Dent 2016;116(3):362-7.

38. Abdel-Azim T, Rogers K, Elathamna E, Zandinejad A, Metz $\mathrm{M}$, Morton D. Comparison of the marginal fit of lithium disilicate crowns fabricated with CAD/CAM technology by using conventional impressions and two intraoral digital scanners. J Prosthet Dent 2015;114(4):554-9.

How to cite this article: Aswani $\mathrm{K}$, Wankhede S, Khalikar A, Deogade S. Accuracy of intraoral digital impression: A review. Ann Prosthodont Restor Dent 2019;5(3):53-7. 